\title{
Estudo do potencial de geração de metano a partir da biodegradação de resíduos sólidos da cidade de Campinas
}

\author{
Jair F. Zanaga Neto*, Jorge L. Paixão Filho.
}

\section{Resumo}

A análise do cenário brasileiro atual e futuro é preocupante, pois está ocorrendo um crescimento significativo quanto ao descarte de resíduos sólidos urbanos (RSU) e matriz energética começou a não suprir as necessidades da sociedade, tornado necessário a busca por outras fontes de energia. O objetivo desse trabalho foi analisar o aproveitamento do biogás produzido pela biodegradação de resíduos orgânicos em aterro sanitário. Este trabalho foi realizado com a análise da caracterização gravimétrica de RSU de uma célula experimental do aterro sanitário Delta A de Campinas. Para a quantificação de $\mathrm{CH} 4$ foi empregado os modelos do IPCC e Scholl Canyon para dois períodos, o tempo de deposição atual (no último dia) e após 30 (trinta) anos do encerramento da célula. Os resultados da geração de $\mathrm{CH} 4$ com os modelos IPCC e Scholl Canyon foram respectivamente de $1.079 .039,61 \mathrm{~kW}$ e $1.048 .930,84 \mathrm{~kW}$, tendo como base a geração $293.790 .736 \mathrm{~kg}$ de RSU diário na cidade. A quantidade de $\mathrm{CH} 4$ gerada pode ser convertida em energia elétrica e ser empregada como suprimento energético diariamente para aproximadamente 149.200 residências (valor teórico).

\section{Palavras-chave: Geração de energia elétrica, fontes renováveis e aquecimento global.}

\section{Introdução}

Com o passar dos anos, técnicas de gerenciamento de resíduos vem tomando grande importância. A operação de aterros sanitários como biorreatores, no qual o aterro não é só um local para o tratamento dos resíduos, mas com redução da massa, volume dos resíduos, gerando o biogás para o aproveitamento energético ${ }^{1}$.

Para a análise do potencial de geração de gás metano foi utilizado como base uma célula experimental instalada no Aterro Sanitário Delta A na cidade de Campinas. A composição gravimétrica dos resíduos foi realizada por Miguel et al (2016). Os modelos utilizados para se determinar o índice de geração do gás metano foram os modelos do IPCC (1996) (Eq.1) e do Scholl Canyon (Eq.2), modelos empíricos amplamente aceitos. Os parâmetros para aplicação do modelo são: potencial de geração de metano do resíduo (Lo), fator de correção de metano (FCM) e a constante de geração de metano (k) (Ensinas, 2003).

$$
\frac{Q_{T, x}=k M_{i} L_{O} e^{-k(T-t)}}{Q_{C H_{4 i}}=k L_{0} M_{i}\left(e^{-k T}\right)} \text { (Eq. 1) }
$$

Onde:

$Q_{C H}=$ Metano gerado no ano i ( $\left.\mathrm{m}^{3} / \mathrm{ano}\right) ; \mathrm{k}=$ constante de geração de metano (1/ano); Lo = potencial de geração de metano $\left(\mathrm{m}^{3}\right.$ de $\mathrm{CH}_{4}$ por tonelada de resíduo); $\mathrm{Mi}=$ quantidade de resíduo depositada no ano i (t/ano); $\mathrm{T}=$ tempo desde o encerramento do aterro ou célula (ano) $\mathrm{T}=0$, para aterros ativos.

\section{Resultados e Discussão}

Na primeira parte dos cálculos da célula experimental do aterro sanitário Delta $\mathrm{A}$ foram utilizados parâmetros adotados como valores padrões, sendo os mais utilizados, o potencial de geração de metano (Lo) igual a $170 \mathrm{~m}^{3}$ e a constante de decaimento $(\mathrm{k})$ igual a 0,05/ano. A quantidade de resíduos depositada na célula experimental durante o tempo de 28 dias $(0,0767$ ano $)$ foi de $9.427,43$ ton e os resultados estão na tabela 1 .

Tabela 1. Resultados dos cálculos (parâmetros adotados).

\begin{tabular}{|c|c|c|}
\hline Modelo & $\begin{array}{c}\text { Último dia } \\
\left(\mathrm{m}^{3} / \text { ano }\right)\end{array}$ & $\begin{array}{c}\text { Após } 30 \text { anos } \\
\left(\mathrm{m}^{3} / \mathrm{ano}\right)\end{array}$ \\
\hline IPCC 1996 & $80.441,06$ & $17.948,82$ \\
\hline SCHOLL CANYON & $80.133,16$ & $17.880,12$ \\
\hline
\end{tabular}

$\mathrm{Na}$ segunda parte dos cálculos da célula experimental, foram utilizados os parâmetros calculados a partir dos dados da célula experimental e dos resíduos da cidade de Campinas ( $\mathrm{LO}=69,6 \mathrm{~m}^{3}$ ) (Tabela 2).

Tabela 2. Resultados dos cálculos (parâmetros calculados).

\begin{tabular}{|c|c|c|}
\hline Modelo & $\begin{array}{c}\text { Último dia } \\
\left(\mathrm{m}^{3} / \mathrm{ano}\right)\end{array}$ & $\begin{array}{c}\text { Após 30 anos } \\
\left(\mathrm{m}^{3} / \mathrm{ano}\right)\end{array}$ \\
\hline IPCC 1996 & $18.609,37$ & $7.961,88$ \\
\hline SCHOLL CANYON & $18.569,02$ & 7944,62 \\
\hline
\end{tabular}

É possível observar uma diferença entre os valores de geração de metano quando comparado os parâmetros calculados e adotados. Essa diferença é devido a características específicas dos resíduos gerados em cada localidade. Portanto é importante a realização de outros trabalhos de caracterização como feito por Miguel et al., (2016) em outros municípios brasileiros, pois a adoção de parâmetros de países desenvolvidos pode gerar dados não compatíveis com a realidade.

\section{Conclusões}

Conclui-se que, para se obter resultados mais precisos, é essencial que ocorra uma separação do RSU de acordo com classe, o tipo e a origem, sendo de extrema importância para a determinação do cálculo da fração de carbono orgânico degradável (COD), pois a partir desse dado é possível calcular a geração de metano.

${ }^{1}$ BOSCOV, M. E. G. Geotécnica Ambiental. 1a ed., SP: Oficina de Textos, 2008.

${ }^{2}$ MIGUEL, M. G.; FILHO, J. L. P.; BENATTI, J. C. B.; LEME, M. A. G. Gravimetric composition of municipal solid waste disposed in a large-scale experimental cell in Southeastern Brazil. International Journal of Environment and Waste Management, vol. 17, $\mathrm{N}^{\circ}$ 2, 2016.

3 ENSINAS, A.V. Estudo da geração de biogás no aterro sanitário Delta em Campinas - SP. Dissertação de Mestrado, Universidade Estadual de Campinas, 129 p., 2003. 